Article

\title{
An Evaluation of the Impact of Hiking Tourism on the Ecological Status of Alpine Lakes-A Case Study of the Valley of Dolina Pięciu Stawów Polskich in the Tatra Mountains
}

\author{
Adam Senetra ${ }^{1}\left[\right.$, Piotr Dynowski ${ }^{1}$ (D) Iwona Cieślak ${ }^{1}\left[\right.$ and Anna Źróbek-Sokolnik ${ }^{2, *}$ (i) \\ 1 Department of Socio-Economic Geography, University of Warmia and Mazury in Olsztyn, \\ Prawocheńskiego Str.15, 10-720 Olsztyn, Poland; adam.senetra@uwm.edu.pl (A.S.); \\ piotr@jezioro.com.pl (P.D.); isidor@uwm.edu.pl (I.C.) \\ 2 Department of Botany and Nature Protection, University of Warmia and Mazury in Olsztyn, Plac Łódzki, \\ 10-727 Olsztyn, Poland \\ * Correspondence: a.zrobeksokolnik@uwm.edu.pl; Tel.: +48-895-234-927
}

Received: 27 February 2020; Accepted: 5 April 2020; Published: 8 April 2020

\begin{abstract}
Eutrophication is one of the major threats to the quality of water in high mountain lakes. The inflow of elements having biological origin may significantly aggravate the ecological status of those ecosystems. For this reason, the aim of this study was to map and assess the impact of anthropogenic pressure on alpine lakes in the valley of Dolina Pięciu Stawów Polskich (known in English as the Valley of Five Polish Lakes) in the Tatra National Park in Poland. The effects of tourism and easy access to alpine lakes on changes in their ecological status were determined. Tourist trails were evaluated based on the difficulty of access to the water surface of analyzed alpine lakes, with a method developed for assessing anthropogenic pressure on aquatic ecosystems. The method, deployed for the first time in 2019, was modified and adapted to the local environmental conditions in the research area. The results of this study indicate that tourism pressure contributes to the growth of submerged vegetation in alpine lakes. The presence of aquatic plants (including vascular plants) shows ecosystem response to water enrichment with biogenic substances. The present findings were used to formulate practical recommendations and propose modifications to the evaluated hiking trails. The research method developed in the study can support analysis and control of tourist traffic, thus reducing anthropogenic pressure on alpine lakes in national parks located in mountain areas.
\end{abstract}

Keywords: alpine lakes; anthropopressure; high mountain lakes; scuba diving; submerged vegetation; Tatra National Park; tourist traffic

\section{Introduction}

Anthropopression (also known as anthropogenic pressure or human pressure) is understood as the totality of human activities (both planned and accidental) and factors directly or indirectly related to human activity that lead to the use of natural resources to meet human needs. As it might be expected, these activities lead to various changes in the natural environment, but most often they are negative changes causing degradation of the natural environment. Anthropopression is most often associated with numerous disturbances in the functioning of basic ecological systems (including changes in the species composition), significant transformation of the landscape, as well as modification of ecological factors existing in nature (e.g., increase in temperature on Earth). In order to prevent or eliminate the negative effects of anthropopressure, numerous and various activities are undertaken to restore or maintain natural habitats, restitution and protection of species, renewing forest communities, and reducing the use of natural resources [1-4]. 
In tourism, the quality of the environment called "natural" (unchanged or changed to a minimal extent by human) or the "anthropogenic" (changed in various, often to a significant extent, by human) plays a key role. The relationship between the environment and tourism is complex, and many human activities can exert an adverse impact on the natural environment. In addition to the direct effects of individual tourist behaviors, tourist infrastructure and tourist facilities are also considerable sources of anthropogenic pressure. The negative impacts of tourism development can be manifested by the gradual degradation of natural resources. However, when tourism is sustainable, it can potentially have a beneficial effect on the environment, thus contributing to environmental protection and conservation. This form of tourism is known as ecotourism, and it has been developing rapidly in recent years. Tourism exerts adverse effects on the environment when the use of natural resources exceeds their regenerative capacity. On the other hand, there is uncontrolled conventional tourism, which is a potential threat to many natural areas located around the world. A disproportionately high influx of tourists can exert massive pressures on a given area leading to soil erosion, increased pollution, waste disposal in seas, loss of natural habitats caused by ecosystem degradation, increased pressure on endangered species, higher risk of forest fire, and even desertification [5-7]. Protected areas are highly valued tourist and recreational places due to their attractive landscapes and high level of biodiversity. This situation exposes these places to intense anthropopressure, which causes significant damage and adverse changes in these areas. The degradation of naturally valuable areas results in the need to take appropriate measures leading to the preservation of elements of nature and the environment that are attractive to tourists, i.e., protection of nature and maintenance of the tourist attractiveness of the region, and thus the possibility of obtaining benefits for tourists by local residents. Mountain areas are characterized by high biodiversity and attractive landscapes, and they are popular tourist sites. The above contributes to the development of tourism infrastructure, and it increases tourist traffic, which intensifies the usually negative effects of anthropopressure on mountain ecosystems, including aquatic ecosystems [8-14]. Global tourism interest also leads to a phenomenon called "overturism" (it occurs when there are too many visitors to a particular destination in some places. This fact overwhelms the destination and shifts the balance from positive experiences to those where tourism becomes unsustainable) [15-17].

It is assumed that lakes are particularly vulnerable to various negative effects of anthropogenic pressures (also in the form of tourism), such as eutrophication, habitat degradation, as well as introduction of alien species, which are frequently inter-related [18-20]. With the listed effects, water eutrophication is one of the most serious human-induced changes in the natural environment. In the EU directives, eutrophication is defined as the undesirable effects of water enrichment with biogenic compounds resulting from human activity. The main sources of biogenic elements which have anthropogenic origin are sewage, fertilizer flows, soil erosion, animal manure and industrial wastewater [11,21,22]. At present, anthropogenic eutrophication is regarded as one of the major risk factors that compromise the quality of inland and coastal waters $[8,11,23-26]$.

Unnatural proliferation of all types of algae (both microalgae and macroalgae, i.e., hydromacrophytes), in water is considered to be the main symptom of eutrophication. Algal growth is stimulated not only by external factors such as sunlight availability and the physicochemical properties of water (nutrient content, temperature, transparency and $\mathrm{pH}$ ), but also by the hydrodynamic regime of a water body, including water disturbance, flow velocity and flow rate [11,27-29]. According to the literature, ecological models are valuable tools for investigating lake eutrophication and managing lake ecosystems $[26,30,31]$. Lake eutrophication models can be classified into several categories based on their complexity, including simple regression or nutrient balance models, water quality models, complex ecological and hydrodynamic models, as well as ecological dynamics models [26,32-34]. The above indicates that the ecological status of water bodies should be assessed based on a full range of biological elements as well as the associated hydromorphological and physicochemical elements. From biological elements, the most sensitive to water enrichment with biogenic substances are planktonic algae (phytoplankton), phytobenthos (mostly diatoms), hydromacrophytes (emergent, 
submersed and floating aquatic plants) and zooplankton [35]. Phytoplankton and phytobenthos are considered to be early indicators of eutrophication of waters because they take nutrients directly from water $[27,35]$. The problem with the method of measuring eutrophication of water using phytoplankton is that phytoplankton is characterized by significant seasonal variation, so environmental assessments based on this indicator may be difficult to carry out. A hydromacrophyte-based model was proposed in this study. Hydromacrophytes take up biogenic compounds from bottom sediments and, in some cases, also from water. The species structure, diversity, and cover density of hydromacrophytes are influenced by water nutrients at a community level [36]. A decrease of the depth range of aquatic vegetation or the disappearance of selected macrophyte communities, such as charophytes, due to decreased light availability (caused by the overgrowth of phytoplankton) are reliable indicators of adverse changes in aquatic ecosystems $[24,37,38]$. The response of hydromacrophytes to nutrient enrichment of water is much slower than that of phytoplankton. Although macroalgae are not early indicators of eutrophication, hydromacrophyte communities are characterized by greater stability. For this reason, they are better predictors of long-term changes in water trophy [35,36,38-40]. For this reason, hydromacrophytes were used in this study as indicators of tourism's direct negative impact on the lakes in the valley of Dolina Pięciu Stawów Polskich (known in English as the Valley of Five Polish Lakes) in the Tatra National Park.

Similar to our previous research [41], this study evaluated alpine water bodies. These lakes are situated at high altitudes (typically in mountain regions), and they are characterized by relatively small size, cold and oligotrophic water, and species-poor communities of flora and fauna [37,41-46]. The literature on hydromacrophytes colonizing lakes in the Tatra Mountains is scant. Publications of Kawecka [47,48] present the flora of the lakes Morskie Oko and Wielki Staw Polski. Studies by Dynowski et al. [41] and Galas [49] have shown occurrence of Potamogeton friesii Rupr. in Lake Morskie Oko. The presence of Batrachium trichophyllum (Chaix) Bosch in Lake Mały Staw Polski in Dolina Pięciu Stawów Polskich was described by Zwijacz-Kozica and Żywiec [50]. Both species are characteristic of mesotrophic and eutrophic lakes, but they have also been encountered in alpine lakes [45,51-54].

It should also be noted that ecological assessments of lakes based on the macrophyte method are increasingly conducted with the assistance of scuba divers. Literature data show that underwater surveys performed by divers are significantly more reliable and less invasive than traditional ones that rely on penetrating the bottom using anchor or dredges [38,40,55-57].

Similar to our previous study [41], it was assumed that tourism and easy access to alpine lakes contribute to changes in the lakes' ecological status (research hypothesis). The environmental impact of tourism is manifested by the increased presence of hydromacrophytes. The research method was tested and, based on the relevant assumptions, adapted to different environmental conditions, land development patterns, tourist trails and the distribution of tourism infrastructure. The aim of this study was to determine whether the macrophyte-based method is a universal tool for assessing the influence of tourism (anthropogenic pressure) and the associated risks on the ecological status of alpine lakes. The assumed research hypothesis was falsifiable by analyzing the presence of hydromacrophytes in six high mountain lakes in the valley of Dolina Pięciu Stawów Polskich in the Tatra National Park. This is one of few studies in Poland and the world to rely on such extensive support from scuba divers to accumulate highly accurate data. The section "Recommendations of the Hiking Trail Changes" shows the possibility of applying the results and conclusions of the presented research in the field of conservation activities and tourism planning in the Tatra Mountains (regards tourism carrying capacity, land development and the course of tourist trails).

\section{Materials and Methods}

\subsection{Presentation of the Studied Area}

Six water bodies in the valley of Dolina Pięciu Stawów Polskich in the Polish part of High Tatra Mountains were studied (Figure 1, Table 1). The Tatras are the tallest mountain range in the central 
part of the Western Carpathians. This mountain massif occupies an area of $785 \mathrm{~km}^{2}$. Only $23 \%$ belongs to Poland, and the remainder lies in Slovakia. The valley of Dolina Pięciu Stawów Polskich is one of the greatest tourist attractions in the Tatra National Park (TNP). The valley was selected for the study due to high levels of tourist traffic, in particular in the areas of Lakes Przedni Staw Polski, Mały Staw Polski and Wielki Staw Polski. One of the greatest attractions in the valley is the Siklawa waterfall, the largest waterfall in Poland which flows directly from Lake Wielki Staw Polski.

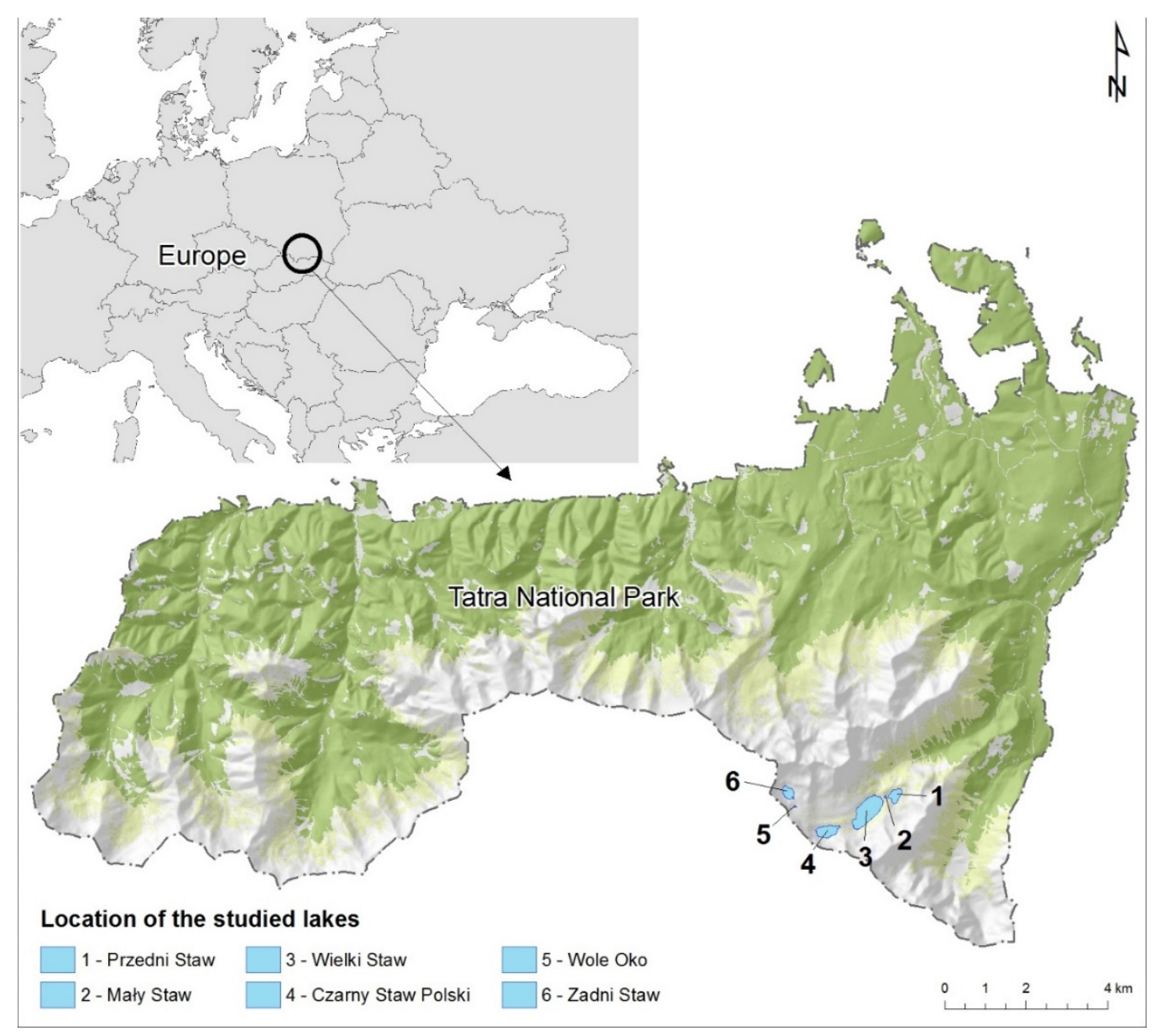

Figure 1. Location of the studied lakes. Source: Own elaboration based on data provided by the Tatra National Park.

Table 1. Alpine lakes in the valley of Dolina Pięciu Stawów Polskich (Source: Own elaboration based on $[58,59])$.

\begin{tabular}{cccc}
\hline Lake & Area (ha) & Maximum Depth (m) & Surface Elevation (m a.s.1.) \\
\hline Przedni Staw Polski & 7.7 & 34.6 & 1668 \\
Mały Staw Polski & 0.2 & 2.1 & 1668 \\
Wielki Staw Polski & 34.4 & 79.3 & 1665 \\
Czarny Staw Polski & 12.7 & 50.4 & 1722 \\
Zadni Staw Polski & 6.5 & 31.6 & 1889 \\
Wole Oko & - & - & 1862 \\
\hline
\end{tabular}

m a.s.l.: meters above sea level.

The studied lakes are surrounded by tall mountains, including Kozi Wierch, the highest Tatra summit that is located entirely within the confines of Poland (2291 m a.s.l.) (Figures 2 and 3) [58,59]. 


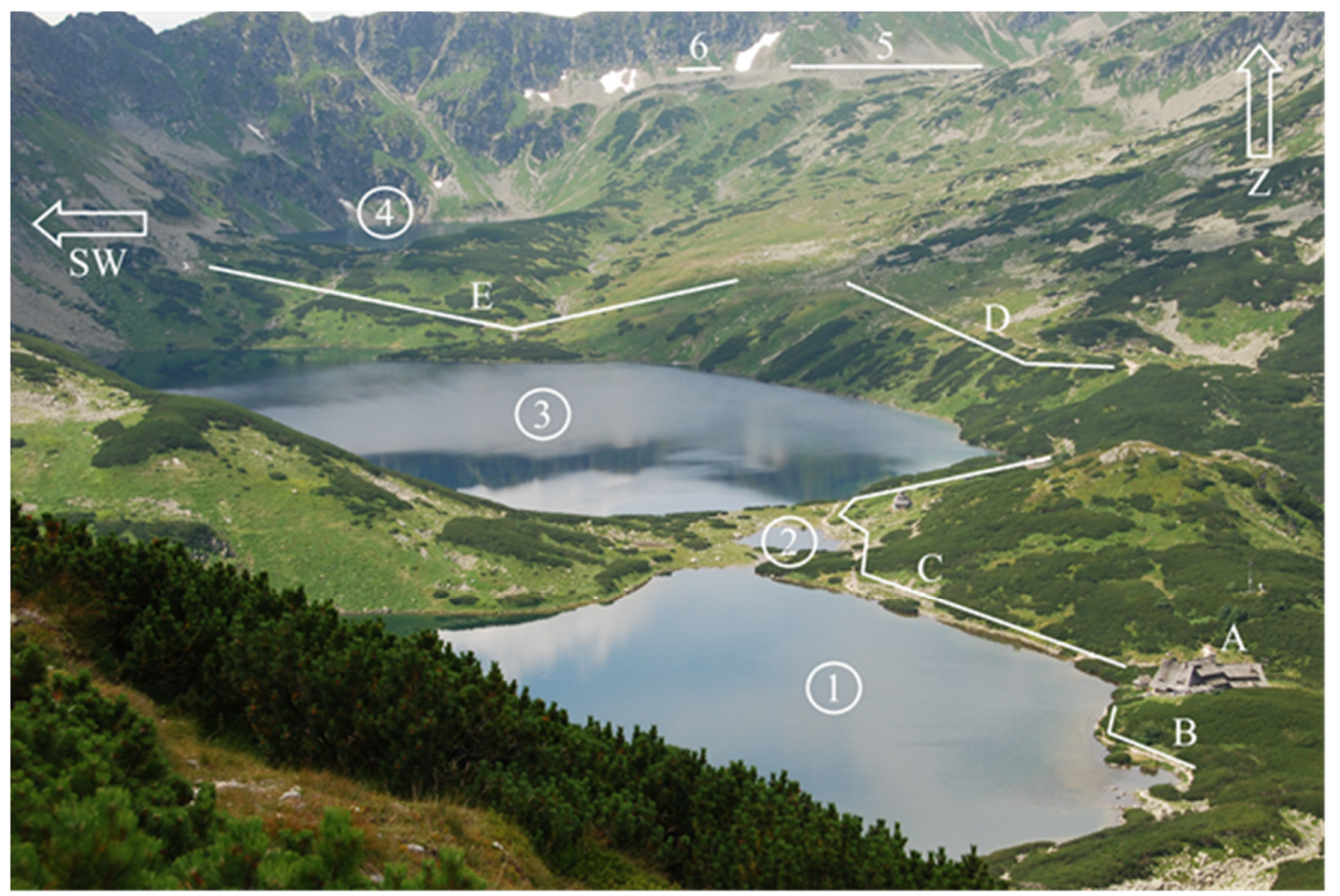

Figure 2. View from the trail to the valley of Dolina Świstówka Roztocka to the studied lakes. 1-Lake Przedni Staw Polski; 2-Lake Mały Staw Polski; 3-Lake Wielki Staw Polski; 4-Lake Czarny Staw Polski; 5-Lake Zadni Staw Polski; 6-Lake Wole Oko; A-Mountain shelter; B-Beginning of the trail to the valley of Dolina Świstówka Roztocka; C-Trail to the Siklawa waterfall; D-Trail to Szpiglasowy Wierch (summit) and Zawrat pass; E-Trail to Szpiglasowy Wierch; SE-Location of Szpiglasowy Wierch relative to cardinal directions; $\mathbf{W}$-Location of Zawrat pass relative to cardinal directions.

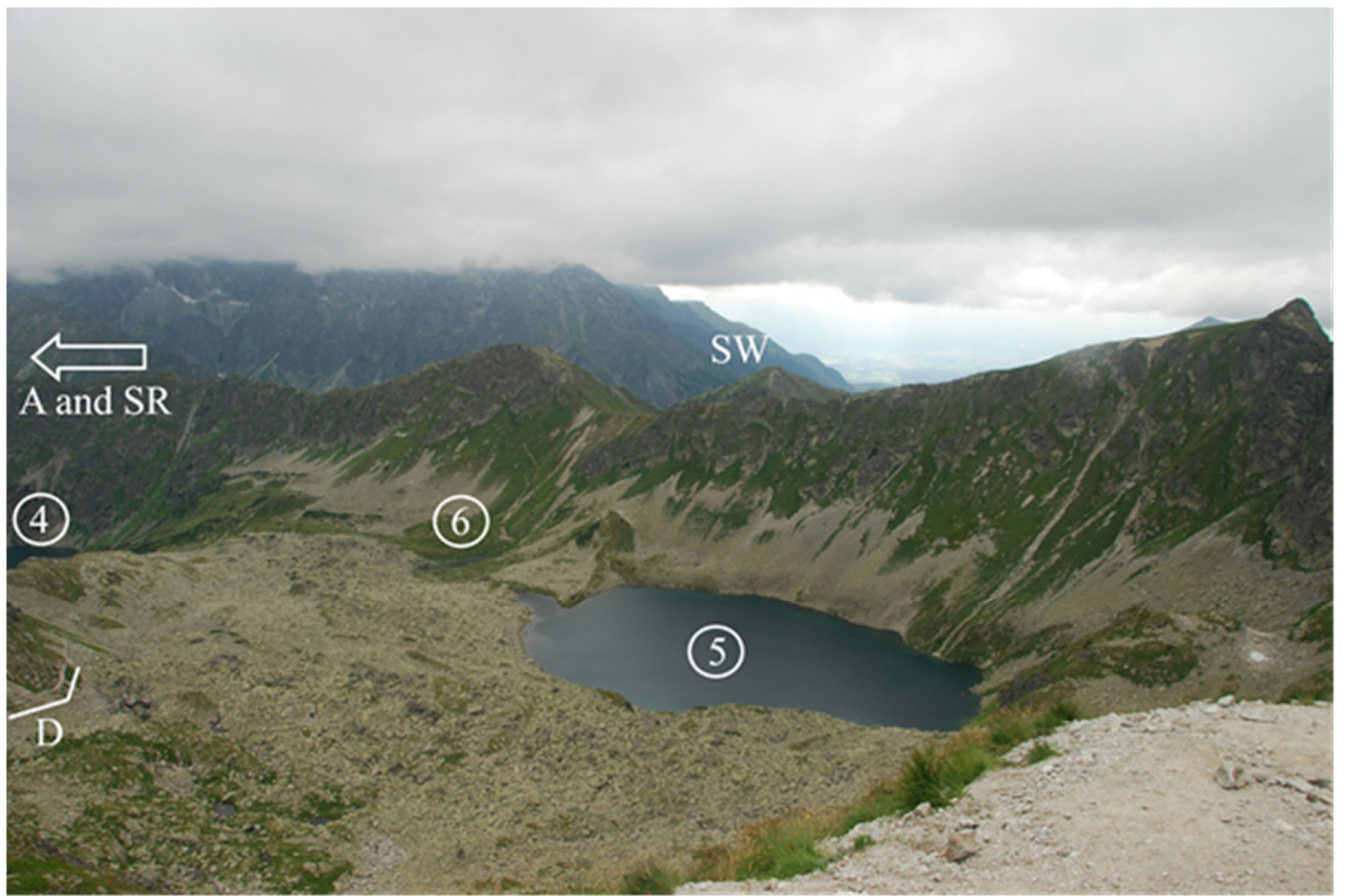

Figure 3. The studied lakes—view from Zawrat pass. 4-Lake Czarny Staw Polski; 5-Lake Zadni Staw Polski; 6-Lake Wole Oko; D-Trail to Szpiglasowy Wierch (summit) and the mountain shelter (A); SE-Szpiglasowy Wierch (summit); A and SR-mountain shelter and the valley of Dolina Świstówka Roztocka. 
Dolina Pięciu Stawów Polskich has an area of $6.5 \mathrm{~km}^{2}$ and a length of $4 \mathrm{~km}$, and it is situated at an altitude of $1625-1900 \mathrm{~m}$ a.s.l. The valley is surrounded by picturesque rocky summits (including Świnica-2228 m a.s.l., Kozi Wierch-2229 m a.s.l., Szpiglasowy Wierch-2176 m a.s.l., and Miedziane-2233 $\mathrm{m}$ a.s.l.) which attract hikers. The studied valley can be accessed via the most popular hiking trail in Poland. Initially, the trail forks, and the easier route leads to Lake Morskie Oko which attracts the highest tourist traffic in the Tatras. The more challenging part of the trail leads to the analyzed valley. The hike from the beginning of the trail to the mountain shelter by Lake Przedni Staw Polski takes around $2.5 \mathrm{~h}$. The trail is not highly strenuous, and it attracts considerable tourist traffic [58-60]. It should be noted that there are no amenities for tourists nor elements of public transport infrastructure on the trail. The only convenience can be horse transport (very expensive), but only in the first, shorter and easier part of trail.

The volume of tourist traffic in the valley of Dolina Pięciu Stawów Polskich has never been described in detail in the literature. Most hikers reach the valley via the main trail leading to the analyzed valley and Dolina Roztoki (which reaches Lake Morskie Oko, one of the greatest attractions in the Tatras). Fewer tourists arrive in the valley via the trail from Dolina Gasienicowa (from Zawrat pass or Krzyżne pass). According to Tatra National Park data regarding ticket sales in 2013-2018, the analyzed area attracts very high levels of tourist traffic (Table 2). Sales data were analyzed for August, the peak tourist month. Tourist traffic in the examined trail accounts for more than $30 \%$ of all entrances to the Tatra National Park. A significant increase was observed relative to August of 2004 and 2009 when traffic in the analyzed trail accounted for $25.9 \%$ and $26.7 \%$ of the total traffic in the Tatra National Park, respectively [61]. The vast majority of tourists entering the trail take the route to Dolina Roztoki. However, field observations and the information obtained from tourist services indicate that approximately $20 \%$ of the visitors hike to Dolina Pięciu Stawów Polskich. Some tourists who reach Dolina Roztoki also continue on the trail to the analyzed valley, similar to tourists walking from Zawrat pass. Therefore, tourist traffic is very high in the investigated area of the Tatras.

Table 2. Number of tourists entering the trail to Dolina Roztoki and Dolina Pięciu Stawów Polskich based on ticket sales data [62].

\begin{tabular}{ccc}
\hline $\begin{array}{c}\text { Entrance in Palenica } \\
\text { Białczańska (years) }\end{array}$ & $\begin{array}{c}\text { Number of Entrances } \\
\text { (persons/day) }\end{array}$ & $\begin{array}{c}\text { All Entrances to the Tatra } \\
\text { National Park (\%) }\end{array}$ \\
\hline 2013 & 5609 & 30.9 \\
2014 & 6140 & 36.4 \\
2015 & 6675 & 34.3 \\
2016 & 7183 & 34.3 \\
2017 & 7445 & 35.6 \\
\hline
\end{tabular}

\subsection{Underwater Surveys and an Evaluation of the Area Surrounding the Analyzed Lakes}

Before conducting research in the Tatra National Park, we obtained two necessary and required by Polish law permits. The first concerned entering the National Park and conducting research-it was granted by the Director of TNP. The second concerned permission to derogate from the bans enshrined in the Nature Conservation Act [63] (descent from the designated trail)—it was granted by the Polish Minister of the Environment.

The study of the lakes in the valley of Dolina Pięciu Stawów Polskich was carried out in September 2017. Underwater observations were attended by specially trained scuba divers with the qualifications of a diver ecologist (Diver Ecologist Level I-PEK1, Advanced Diver Ecologist Level II-PEK2 and Ecologist Diver Instructor-MEK). The divers were accompanied by two researchers on the boat, who recorded in GPS receivers the geographical positions indicated during underwater research. During each diving session (each session lasted up to $2 \mathrm{~h}$ ), the divers described the encountered vegetation on special plates with tables containing fields where species names, coverage area, proportion of each species and depth of occurrence were entered. The lake bottom was explored within the boundaries 
of the phytolittoral zone. A total of 95 phytosociological relevés were acquired (70 in Lake Przedni Staw, 25 in Lake Mały Staw) according to the procedure described by Braun-Blanquet [64]. On this basis, the coverage and exact range of occurrence of hydromacrophytes was determinated. Coverage of the bottom of the lake by hydromacrophytes at the level above $25 \%$ per $1 \mathrm{~m}^{2}$ was considered as a place where macroalgae formed a community. If, at a given location the bottom coverage by hydromacrophytes was less than $25 \%$ per $1 \mathrm{~m}^{2}$-this was considered as a species occurrence site and it was not considered in this manuscript. The shores of both lakes were also examined to determine the intensity of tourism pressure.

The geographic coordinates of the inspected areas were determined and analyzed with ArcGIS 10.5 software (ESRI Inc., Redlands, CA, USA). The evaluated tourist sites were assigned attributes, linear and surface layers, subject to need and the type of the observed phenomena. The above approach facilitated spatial analyses (with the use of the available ArcGIS tools) of the intensity of anthropogenic pressure in different segments of tourist trails and the concentration of hydromacrophytes in each lake. The results of spatial analyses were used to verify the research hypothesis.

\subsection{Determining the Degree of Anthropogenic Pressure into the Studied Area}

The degree of anthropopressure was evaluated based on an indicator relating to the presence of submerged vegetation (filamentous algae, bryophytes and vascular plants). The deployed methodology relied on a modification of the approach that had been used in a previous study of alpine lakes in the Tatras [41]. The study area was divided into buffer zones based on the distribution of the analyzed plants relative to the examined segments of the tourist trail. In Lake Przedni Staw Polski, the maximum depth of aquatic plants was $11.5 \mathrm{~m}$, and the maximum distance between plants and the lake shore (trail) was $60 \mathrm{~m}$. In Lake Mały Staw Polski, the maximum depth of submerged vegetation was $1.8 \mathrm{~m}$, which was identical to the lake's maximum depth (plants were distributed across the entire lake bottom). Due to the small area of Lake Mały Staw Polski (15.6 a), the presence of hydromacrophytes was analyzed in buffer zones within a $30 \mathrm{~m}$ radius from the shore. Buffer zones were not established for the remaining lakes where submerged vegetation was not identified. The tourist trail was divided into 100-m-long segments. A total of 31 segments were mapped: 11 in Lake Przedni Staw Polski, 4 in Lake Mały Staw Polski, 9 in Wielki Staw Polski, 5 in Lake Czarny Staw Polski, 2 in Lake Wole Oko, and 2 in Lake Zadni Staw Polski. Segments number 11 and 14 remain under the combined influence of two lakes and form a shared area; therefore, the corresponding results were presented for 33 cases. In each of the 31 trail segments, lake accessibility was evaluated in the proposed buffer zones.

The difficulty of access to each of the examined alpine lakes was evaluated with the use of four parameters: distance from the lake shore, average trail height above the lake surface, presence of trees and shrubs, and presence of boulders and steep rock surfaces. The significance of each parameter was determined with the use of weights (Table 3) relating to local landform and tourism pressure. Weights were assigned on a three-point grading scale to determine the difficulty of access to each of the studied lakes:

1-corresponds to a situation when access to examined lakes was very difficult or even impossible,

2-corresponds to a situation when access to examined lakes was difficult, and

3 -corresponds to a situation when access to examined lakes was with minor obstacles or easy.

Table 3. Weights for lake accessibility in different segments of the analyzed trail (Source: [41]).

\begin{tabular}{|c|c|c|c|c|c|}
\hline Weight & Parameter & $\begin{array}{l}X_{1}: \text { Distance from } \\
\text { the Lake Shore }(\mathrm{m})\end{array}$ & $\begin{array}{l}\mathrm{X}_{2} \text { : Average Trail } \\
\text { Height above the } \\
\text { Lake Surface }(\mathrm{m})\end{array}$ & $\begin{array}{c}\mathrm{X}_{3} \text { : Presence of Trees and } \\
\text { Shrubs Obstructing Lake } \\
\text { Access (\%) }\end{array}$ & $\begin{array}{c}\mathrm{X}_{4}: \text { Presence of Boulders } \\
\text { and Steep Rock Surfaces } \\
\text { Obstructing Lake } \\
\text { Access (\%) }\end{array}$ \\
\hline & 1 & above 6 & above 1 & above 50 & above 50 \\
\hline & 2 & $(3-6)$ & $(0.5-1)$ & $(25-50)$ & $(25-50)$ \\
\hline & 3 & up to 3 & below 0.5 & below 25 & below 25 \\
\hline
\end{tabular}


The sum of the weights describing lake accessibility in every segment of the analyzed trail was divided into accessibility classes $-\mathrm{K}_{\mathrm{D}}$. The weights were divided at equal intervals because parameters could have identical weights. The following accessibility classes were determined $\left(\mathrm{K}_{\mathrm{D}}\right)$ :

(a) Class I corresponds to a situation when access to examined lakes was with minor obstacles or easy access: (10-12),

(b) Class II corresponds to a situation when access to examined lakes was difficult: (7-9),

(c) Class III corresponds to a situation when access to examined lakes was very difficult or even impossible: (4-6).

The area occupied by submerged vegetation was determined with using the Jenks natural breaks classification method [65]. This approach is used to analyze unevenly distributed data. Three classes of plant cover, $\mathrm{K}_{\mathrm{P}}$, were identified. Separate classes of plant cover were applied to two lakes that differed considerably in area and, consequently, plant cover (Table 4).

Table 4. Classes of plant cover $\left(\mathrm{K}_{\mathrm{P}}\right)$.

\begin{tabular}{cc}
\hline Lake Przedni Staw Polski & Lake Mały Staw Polski \\
\hline Class I of plant cover: $\left(1998-3331 \mathrm{~m}^{2}\right)$ & Class I of plant cover: $\left(890-1129 \mathrm{~m}^{2}\right)$ \\
Class II of plant cover: $\left(256-1997 \mathrm{~m}^{2}\right)$ & Class II of plant cover: $\left(725-889 \mathrm{~m}^{2}\right)$ \\
Class III of plant cover: $\left(0-255 \mathrm{~m}^{2}\right)$ & Class III of plant cover: $\left(0-724 \mathrm{~m}^{2}\right)$ \\
\hline Classes of plant cover were not determined for the remaining lakes due to the absence of vegetation.
\end{tabular}

It was assumed that easy lake access contributes to anthropogenic pressure due to a higher risk of contamination with organic and inorganic matter. Human-caused pollution can be directly responsible for the growth of submerged vegetation. Plants were most likely to appear in segments of the analyzed trail belonging to class I of accessibility $\left(\mathrm{K}_{\mathrm{D}}\right)$, and these segments were assigned to class I of plant cover $\left(K_{\mathrm{P}}\right)$. Segments in classes II and III of accessibility corresponded to classes II and III of plant cover, respectively [41].

\section{Results}

Submersed vegetation was identified only in two of the examined lakes (Przedni Staw Polski and Mały Staw Polski). These plants were observed at all segments of the hiking trail in the vicinity of those water bodies. In the remaining lakes, submersed vegetation was absent in areas remaining under the influence of the hiking trail. Only one vascular plant species, Batrachium trichophyllum (Chaix) Bosch, was identified. In Lake Przedni Staw, the bottom area covered by B. trichophyllum was about $8700 \mathrm{~m}^{2}$ (which constitutes $11.3 \%$ of the entire lake bottom), of which on the area of $6500 \mathrm{~m}^{2}$, the bottom coverage is from $100 \%$ to $50 \%$, while on the surface of $2200 \mathrm{~m}^{2}$-from $50 \%$ to $25 \%$. In the case of Lake Mały Staw, B. trichophyllum covers an area of about $1560 \mathrm{~m}^{2}$ (representing $78 \%$ of the entire bottom of the pond), of which on an area of $885 \mathrm{~m}^{2}$, the bottom coverage is from $100 \%$ to $50 \%$, and on an area of $675 \mathrm{~m}^{2}$-from $50 \%$ to $25 \%$. The areas colonized by this species were presented in maps (Figures 4-8) to verify the research hypothesis. The largest areas colonized by B. trichophyllum in $60 \mathrm{~m}$ buffer zones from the trail were found in segments number 1, 2, 6 and 7 along the northern and south-eastern shores of Lake Przedni Staw Polski. In segments number 3, 4 and 5, this hydromacrophyte species formed isolated islands on the bottom of the lake. Batrachium trichophyllum covered smaller areas along the southern shore of the lake (segments number 9 and 10). 


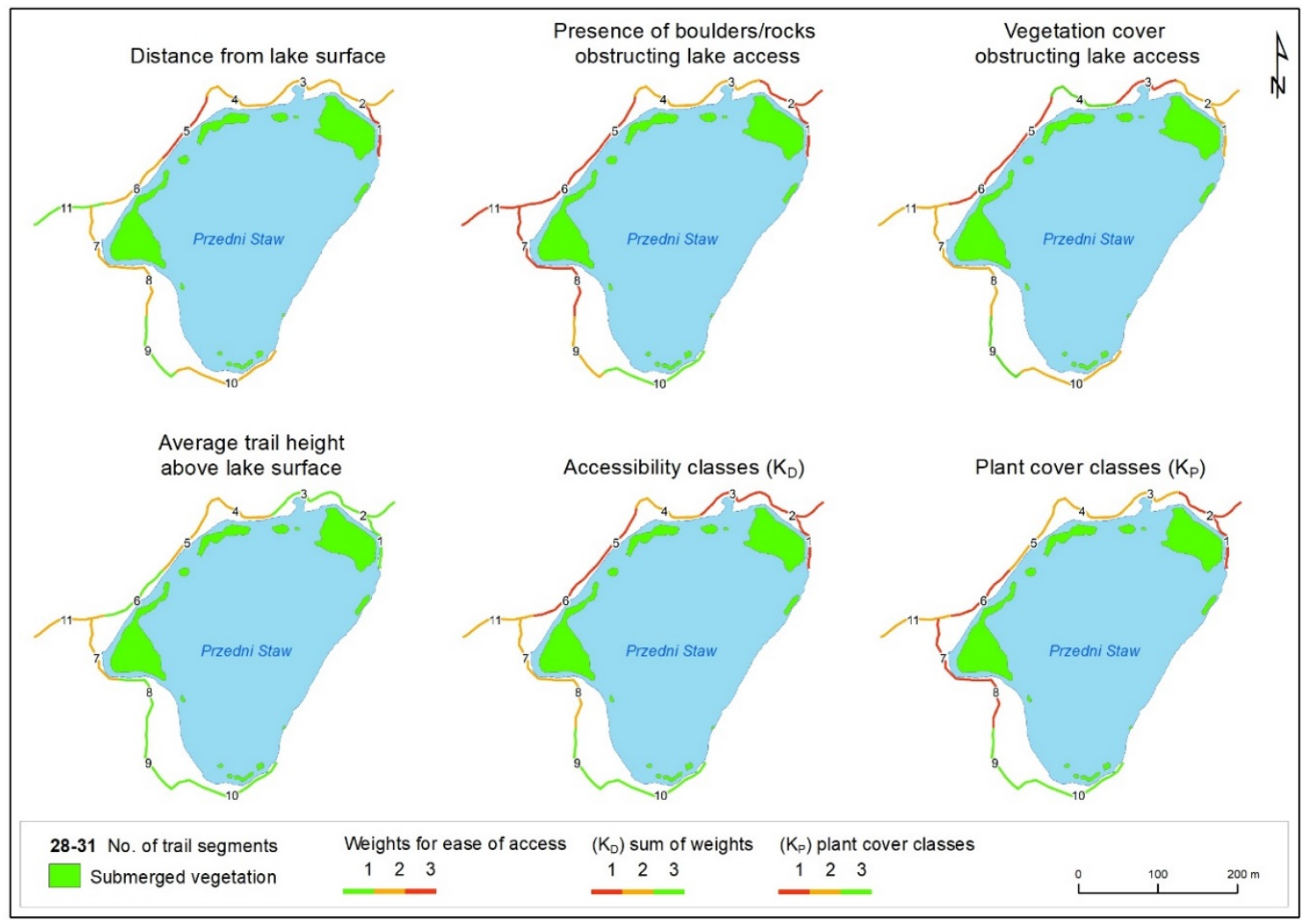

Figure 4. Weights for classes of lake accessibility $\left(K_{D}\right)$ and classes of plant cover $\left(K_{P}\right)$ in Lake Przedni Staw Polski.

The weights of selected parameter (Table 3) describing access to each of the lakes are graphically presented (Figures $4-8)$. The classes of lake accessibility $\left(K_{D}\right)$ and classes of plant cover $\left(K_{P}\right)$ within buffer zones in each segment of the hiking trail were also presented in the above figures. As determined previously, submersed vegetation was identified only in Lakes Przedni Staw Polski and Mały Staw Polski. The presented data (Figures 4 and 5) indicate that five trail segments by Lake Przedni Staw Polski and three segments by Lake Mały Staw Polski were characterized by considerable ease of access (class I). Only two segments of the trail (number 9 and 10) by Lake Przedni Staw Polski were characterized by difficult access and, consequently, the lowest plant cover (class III). Easy or relatively easy access to the studied lakes was responsible for high plant cover (class I) in four segments and moderate plant cover (class II) in three segments of the trail. Considerable plant cover was also noted on the opposite shore of Lake Przedni Staw Polski (eastern shore, segments number 6, 7, 8 and 11) which is easily accessible to visitors.

Classes of lake accessibility $\left(\mathrm{K}_{\mathrm{D}}\right)$ and classes of plant cover $\left(\mathrm{K}_{\mathrm{P}}\right)$ in each segment of the analyzed trail are presented in Table 5. Full correspondence between accessibility class and plant cover class is denoted by " + ", the absence of correspondence in two classes is denoted by " - ", and the absence of correspondence in one class is denoted by " $+/{ }^{\prime \prime}$.

Based on the methodological assumptions adopted for the purposes of the study, class I of lake accessibility should correspond to class I of plant cover, class II of lake accessibility-to class II of plant cover, and class III of lake accessibility-to class III of plant cover. The correspondence between parameters $K_{D}$ and $K_{P}$ is presented in Table 6. The degree of correspondence between classes was generally high in the analyzed lakes. A situation when the obtained parameters $K_{D}$ and $K_{P}$ differed by two classes was noted in only one case (segment number 14). Full correspondence was observed in 22 cases, which validates the correctness of methodological assumptions. 


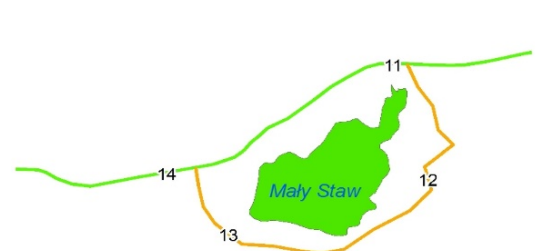

Distance from lake surface

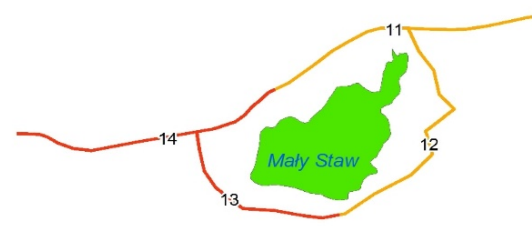

Vegetation cover obstructing lake access

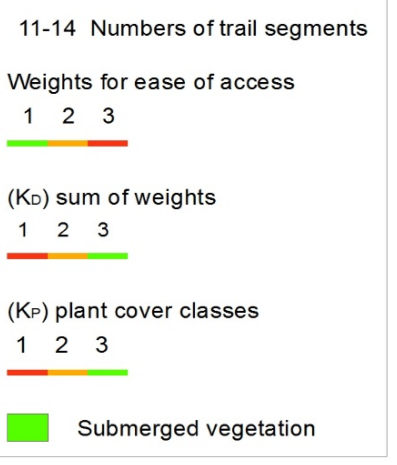

0

50 $100 \mathrm{~m}$
Presence of boulders/rocks obstructing lake access
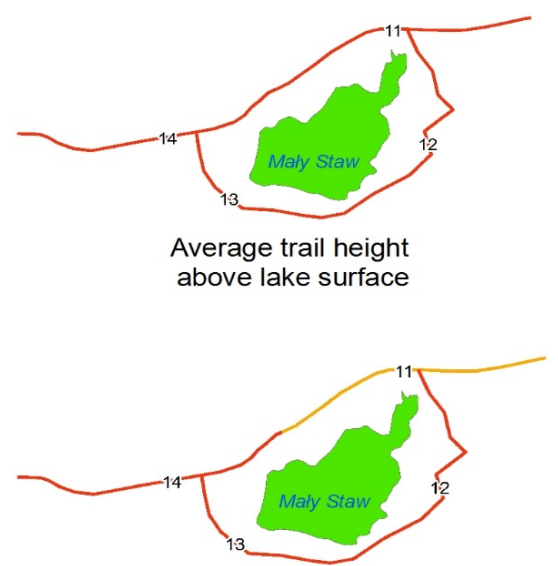

Accessibility classes $\left(K_{D}\right)$

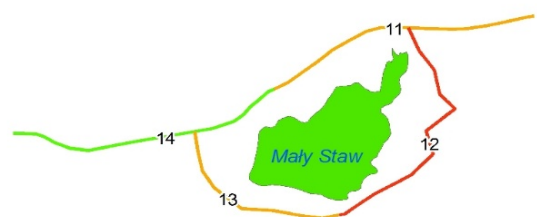

Plant cover classes $\left(K_{P}\right)$

Figure 5. Weights for classes of lake accessibility $\left(\mathrm{K}_{\mathrm{D}}\right)$ and classes of plant cover $\left(\mathrm{K}_{\mathrm{P}}\right)$ in Lake Mały Staw Polski.

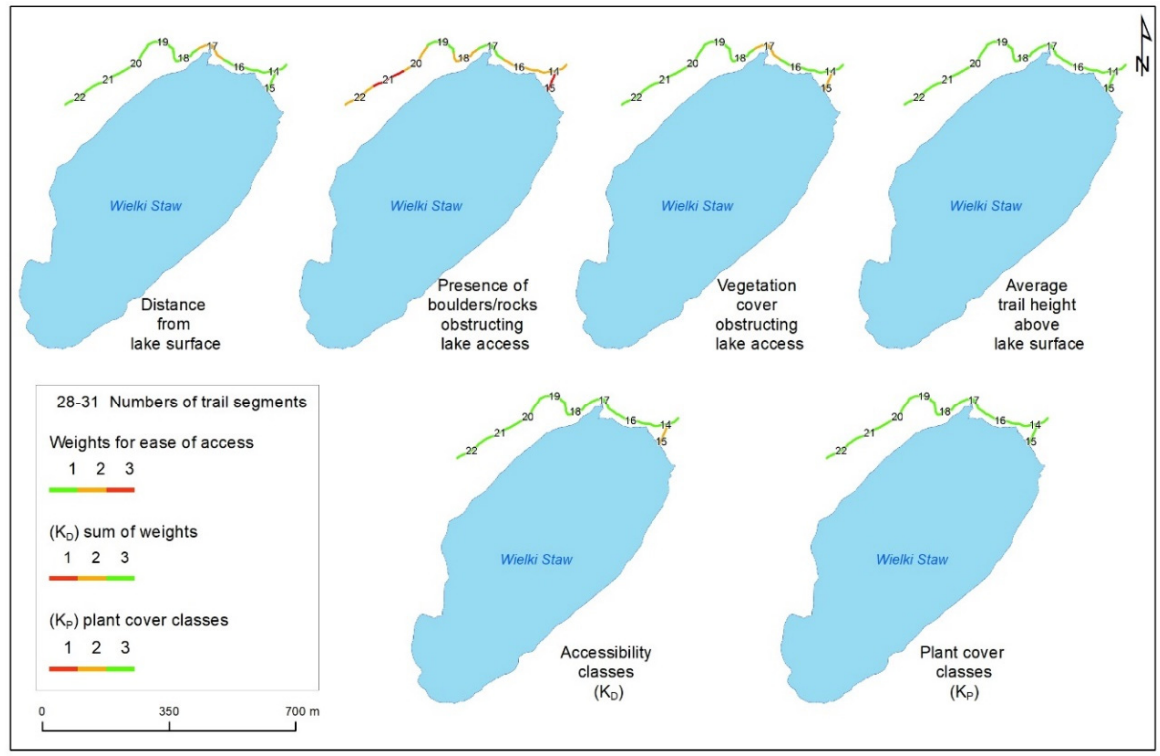

Figure 6. Weights for classes of lake accessibility $\left(K_{D}\right)$ and classes of plant cover $\left(K_{P}\right)$ in Lake Wielki Staw Polski. 


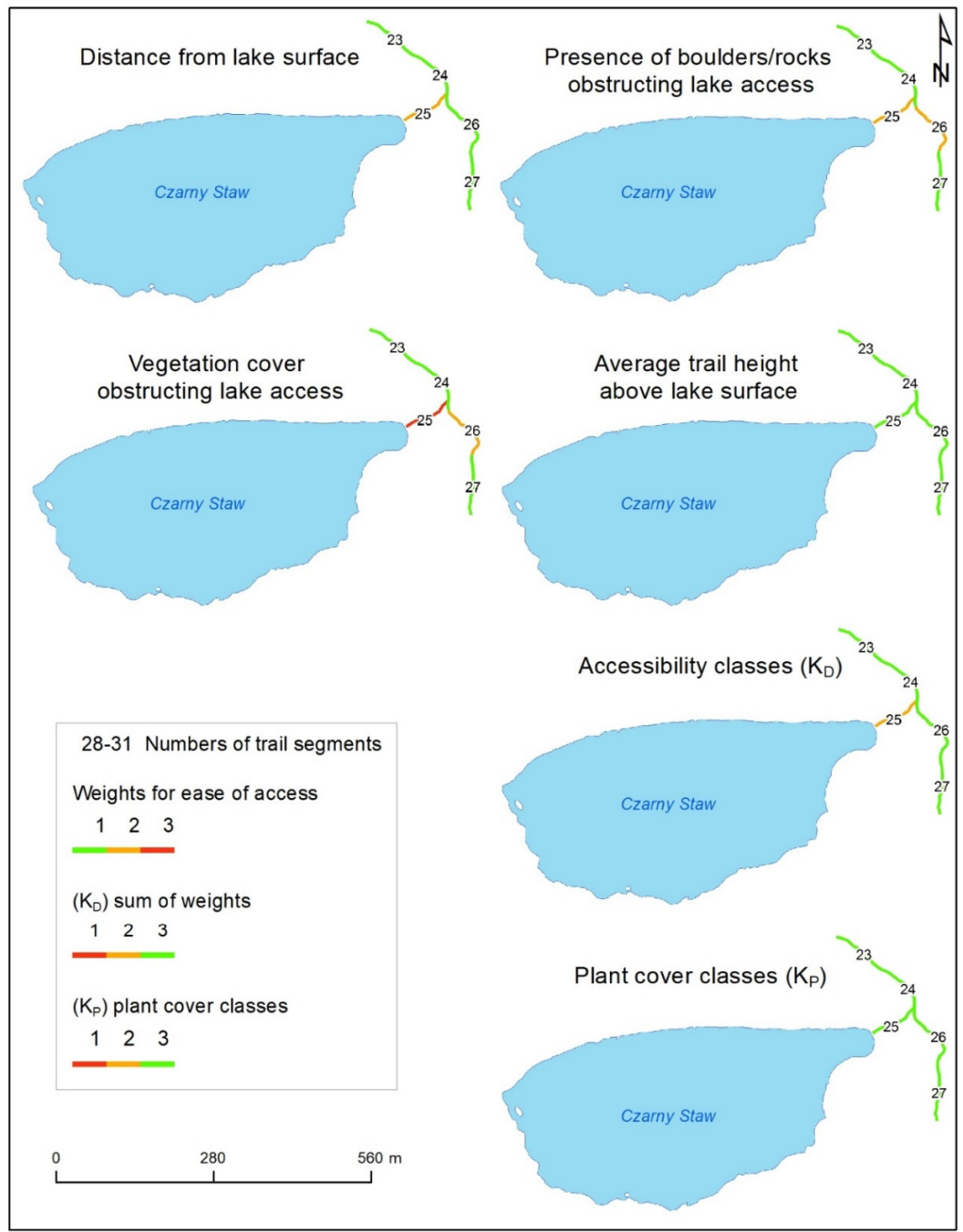

Figure 7. Weights for classes of lake accessibility $\left(K_{D}\right)$ and classes of plant cover $\left(K_{P}\right)$ in Lake Czarny Staw Polski.

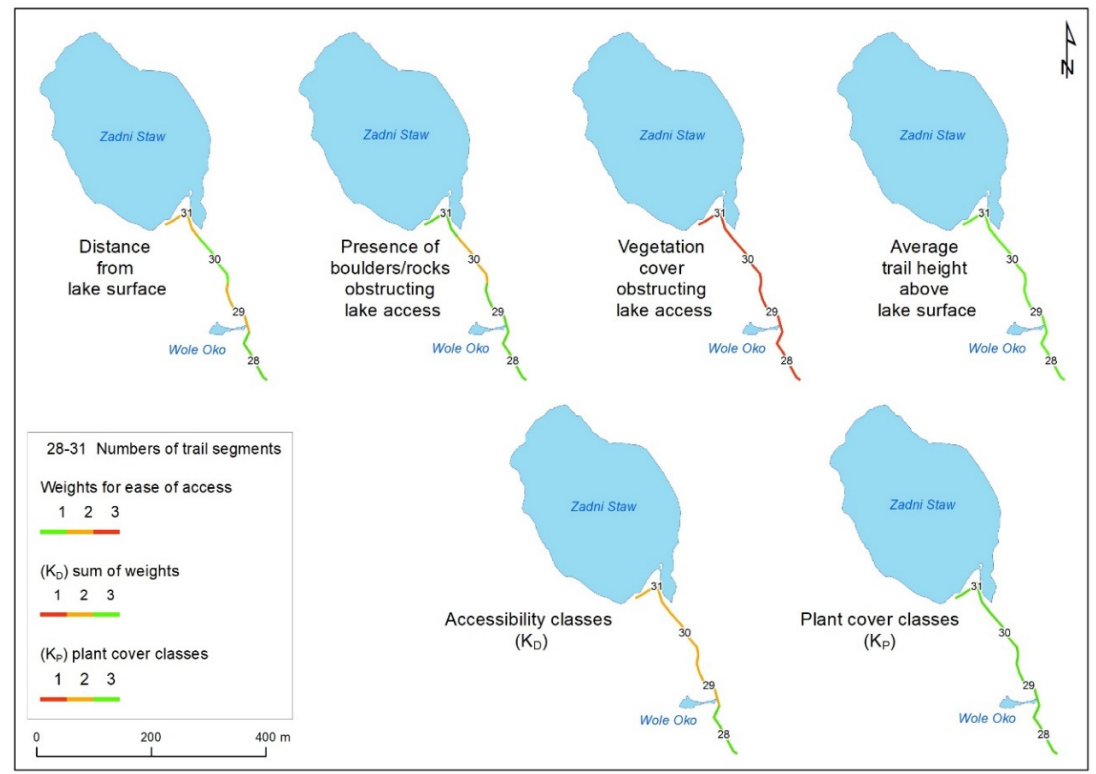

Figure 8. Weights for classes of lake accessibility $\left(\mathrm{K}_{\mathrm{D}}\right)$ and classes of plant cover $\left(\mathrm{K}_{\mathrm{P}}\right)$ in Lakes Zadni Staw Polski and Wole Oko. 
Table 5. Weights for lake accessibility, classes of accessibility of and classes of plant cover in the evaluated trail segments.

\begin{tabular}{|c|c|c|c|c|c|c|c|}
\hline \multirow[t]{2}{*}{$\begin{array}{l}\text { Segment } \\
\text { of Trail }\end{array}$} & \multicolumn{4}{|c|}{$\begin{array}{c}\text { Parameters and } \\
\text { Weights for Segments }\end{array}$} & $\begin{array}{l}\text { Sum of Weights; Class } \\
\text { of Accessibility }\left(K_{D}\right)\end{array}$ & \multirow{2}{*}{$\begin{array}{l}\text { Plant Cover }\left(\mathrm{m}^{2}\right) ; \text { Class } \\
\text { of Plant Cover }\left(\mathrm{K}_{\mathrm{P}}\right)\end{array}$} & \multirow[t]{2}{*}{$\begin{array}{c}\text { Correspondence } \\
\text { between } K_{D} \text { and } K_{P}\end{array}$} \\
\hline & & \multicolumn{4}{|c|}{ Przedni Staw Polski } & & \\
\hline & $X_{1}$ & $X_{2}$ & $\mathrm{X}_{3}$ & $\mathrm{X}_{4}$ & & & \\
\hline 1 & 3 & 3 & 2 & 3 & $11-(\mathrm{I})$ & $333-(\mathrm{I})$ & + \\
\hline 2 & 2 & 3 & 2 & 3 & $10-(\mathrm{I})$ & $3185-(\mathrm{I})$ & + \\
\hline 3 & 2 & 3 & 3 & 2 & $10-(\mathrm{I})$ & 1997-(II) & $+/-$ \\
\hline 4 & 2 & 2 & 1 & 2 & 7-(II) & 1032 -(II) & + \\
\hline 5 & 3 & 2 & 3 & 3 & $11-(\mathrm{I})$ & 1314 -(II) & $+/-$ \\
\hline 6 & 2 & 3 & 3 & 3 & $11-(\mathrm{I})$ & $2270-(\mathrm{I})$ & + \\
\hline 7 & 2 & 2 & 2 & 3 & 9 -(II) & $2948-(\mathrm{I})$ & $+/-$ \\
\hline 8 & 2 & 1 & 2 & 3 & 8 -(II) & $2836-(\mathrm{I})$ & $+/-$ \\
\hline 9 & 1 & 1 & 1 & 2 & 5-(III) & $19-(\mathrm{III})$ & + \\
\hline 10 & 2 & 1 & 2 & 1 & 6 -(III) & 255-(III) & + \\
\hline 11 & 1 & 2 & 2 & 3 & 8 -(II) & 1432 -(II) & + \\
\hline \multicolumn{8}{|c|}{ Mały Staw Polski } \\
\hline 11 & 1 & 3 & 2 & 3 & 9-(II) & $871-(\mathrm{II})$ & + \\
\hline 12 & 2 & 3 & 2 & 3 & $10-(\mathrm{I})$ & 1129 -(I) & + \\
\hline 13 & 2 & 3 & 3 & 3 & $11-(\mathrm{I})$ & $889-(\mathrm{II})$ & $+/-$ \\
\hline 14 & 1 & 3 & 3 & 3 & $10-(\mathrm{I})$ & $724-(\mathrm{III})$ & - \\
\hline \multicolumn{8}{|c|}{ Wielki Staw Polski } \\
\hline 14 & 1 & 1 & 1 & 2 & 5-(III) & 0 -(III) & + \\
\hline 15 & 1 & 1 & 2 & 3 & $7-(\mathrm{II})$ & 0 -(III) & $+/-$ \\
\hline 16 & 1 & 1 & 1 & 2 & 5-(III) & 0 -(III) & + \\
\hline 17 & 2 & 1 & 2 & 1 & 6 -(III) & 0 -(III) & + \\
\hline 18 & 1 & 1 & 1 & 2 & 5-(III) & 0 -(III) & + \\
\hline 19 & 1 & 1 & 1 & 1 & 4-(III) & $0-(\mathrm{III})$ & + \\
\hline 20 & 1 & 1 & 1 & 2 & 5-(III) & 0 -(III) & + \\
\hline 21 & 1 & 1 & 1 & 3 & 6 -(III) & 0 -(III) & + \\
\hline 22 & 1 & 1 & 1 & 2 & 5-(III) & 0 -(III) & + \\
\hline \multicolumn{8}{|c|}{ Czarny Staw Polski } \\
\hline 23 & 1 & 1 & 1 & 1 & 4 -(III) & 0 -(III) & + \\
\hline 24 & 1 & 1 & 1 & 1 & 4-(III) & 0 -(III) & + \\
\hline 25 & 2 & 1 & 3 & 2 & 8 -(II) & 0 -(III) & $+/-$ \\
\hline 26 & 1 & 1 & 2 & 2 & 6-(III) & 0 -(III) & + \\
\hline 27 & 1 & 1 & 1 & 1 & 4-(III) & 0 -(III) & + \\
\hline \multicolumn{8}{|c|}{ Wole Oko } \\
\hline 28 & 1 & 1 & 3 & 1 & 6-(III) & 0 -(III) & + \\
\hline 29 & 2 & 1 & 3 & 1 & 7-(II) & 0 -(III) & $+/-$ \\
\hline \multicolumn{8}{|c|}{ Zadni Staw Polski } \\
\hline 30 & 1 & 1 & 3 & 2 & $7-(\mathrm{II})$ & 0 -(III) & $+/-$ \\
\hline 31 & 2 & 1 & 3 & 1 & 7-(II) & 0 -(III) & $+/-$ \\
\hline
\end{tabular}

Green color-there is a full correspondence between class of $K_{D}$ and $K_{P}$; Yellow color-there is a difference by 1 class in correspondence between class of $\mathrm{K}_{\mathrm{D}}$ and $\mathrm{K}_{\mathrm{p}}$; Red color-there is a difference by 2 classes in correspondence between class of $K_{D}$ and $K_{P}$.

Table 6. The degree of correspondence between class of lake accessibility $\mathrm{K}_{\mathrm{D}}$ and class of plant cover $\mathrm{K}_{\mathrm{P}}$ in the evaluated segments of trail.

\begin{tabular}{cccc}
\hline Lake & $\begin{array}{c}\text { Full } \\
\text { Correspondence }\end{array}$ & $\begin{array}{c}\text { Absence of } \\
\text { Correspondence } \\
\text { Difference by 1 Class }\end{array}$ & $\begin{array}{c}\text { Absence of } \\
\text { Correspondence } \\
\text { Difference by 2 Classes }\end{array}$ \\
\hline Przedni Staw Polski & 7 & 4 & 0 \\
Mały Staw Polski & 2 & 1 & 1 \\
Wielki Staw Polski & 8 & 1 & 0 \\
Czarny Staw Polski & 4 & 1 & 0 \\
Wole Oko & 1 & 1 & 0 \\
Zadni Staw Polski & 0 & 2 & 1 \\
Total & 22 & 10 & 0 \\
\hline
\end{tabular}

Green color-there is a full correspondence between class of $K_{D}$ and $K_{P}$; Yellow color-there is a difference by 1 class in correspondence between class of $\mathrm{K}_{\mathrm{D}}$ and $\mathrm{K}_{\mathrm{p}}$; Red color-there is a difference by 2 classes in correspondence between class of $K_{D}$ and $K_{P}$. 


\section{Discussion}

As mentioned in the introduction, a major threat to the environment is tourism related to the use of the immediate vicinity of the lakes. The location of tourist facilities and tourist activities such as fishing, sunbathing, and sailing, promotes the degradation of the area. The result is, among others, trampling, littering, changing the shoreline of lakes, disrupting animal reproduction and other effects regarding the degradation of aquatic ecosystems [19,66]. According to Dokulil [19], a lake that is suitable for tourism should be characterized by easy access, availability of tourist infrastructure, warm surface water temperature (preferably above $20^{\circ} \mathrm{C}$ ), and high water quality (clean water). The cited author concluded that oligo-mesotrophic lakes best meet the above criteria. In several of the analyzed lakes in the TNP, ease of access was positively correlated with the presence of hydromacrophytes (Figures 4 and 5; Tables 5 and 6). The above was observed in Lakes Przedni Staw Polski and Mały Staw Polski, which are situated in the direct vicinity of a mountain shelter where tourist traffic is particularly high (Figure 4, segments number 1 and 2). The shelter is the only tourist facility offering accommodation, meals and other services (such as bathrooms) in the investigated area. Tourists also bring and consume their own food, rest and contemplate nature around the shelter, and some visitors break the rules by, for example, feeding water birds. Water temperature is not an important parameter in the TNP because bathing and swimming are prohibited in the analyzed lakes. For this reason, the correlations observed near the shelter do not apply to the lakes that are less available and less frequently visited due to the absence of tourist infrastructure. A situation when the obtained parameters $K_{D}$ and $K_{P}$ differed by two classes that appeared in Lake Mały Staw (segment number 14) can be explained by the fact that this section is a transition section between Lake Mały Staw and Lake Wielki Staw. Due to this fact, during spatial analyses, a small part of segment 14 , and hence, the buffer assigned to this section, covered vegetation occurring in Mały Staw. Due to this fact, during spatial analyses, a small part of route 14 , and hence, the buffer assigned to this section, covered vegetation occurring in Lake Mały Staw. This resulted in the described absence of correspondence. Differences by one class, between parameters $K_{D}$ and $K_{P}$, observed in the case of segment number 13 could be due to a too short shoreline of lake in relation to the length of the section on which the trail was divided. In relation to Lake Przedni Staw's observed differences, these could be due to the type of bottom of this reservoir (stones, rock outcrops), which prevented bottom settlement by hydromacrophytes (segments number 3 and 5). On the other hand, there may have been a situation (near the segments number 7 and 8 ) that promoted the development of vegetation-favorable exposure on the slopes, low depth and appropriate base. In the case of other lakes, the discrepancies between the $K_{D}$ and $K_{P}$ parameters observed in relation to some segments could be due to the fact that there were no legal hiking trails in these segments. These segments belonged to illegal hiking trails trampled by tourists, which means that they were not as busy as legal trails. For this reason, there was less tourist pressure on the lakes in these segments, which may result in less nutrients being put into the water and less vegetation.

The impact of anthropopression on lakes located in the Tatra National Park has been studied by numerous researchers. These researchers did not deal with determining the impact of the presence of tourists on changes in the trophy of mountain lakes, but the topic of their research was assessment of the composition of lake water for many years [67], or investigation of the composition of sediment cores to examine the recent environmental history of high mountain lakes in the Polish Tatra Mountains $[11,68]$. The published data suggest that the content of biogenic elements (with a predominance of nitrogen and phosphorus compounds) in the studied water bodies has increased over the years [11,67-70]. However, the correlations between tourism pressure, including easy lake access, and changes in the ecological status of alpine lakes, remain insufficiently researched. Alpine lakes are characterized by low trophy (and scant vegetation) and high ecological sensitivity, which implies that even small inflows of elements having a biogenic nature which are coming from the catchment can destroy ecological balance of the water bodies [71-73]. The above is manifested by the presence of semi-submerged and shore vascular plants in areas where accumulating sediments form a nutritional layer. According to the 2014 report of the Alpine Macrophyte Geographical Intercalibration Group, hydromacrophyte communities 
in alpine lakes are generally composed of more or less dense stands dominated by sensitive taxa, mostly Charophytes [45]. Regardless of its depth of occurrence, Batrachium trichophyllum (Chaix) Bosch is considered as an indicator of alpine lake degradation. In this study, the growth of Batrachium trichophyllum (Chaix) Bosch was most intensive in Lake Mały Staw Polski at a depth of 0.5-1 m. In Lake Przedni Staw Polski, the above species was identified within a broader depth range of $1.5-4.0 \mathrm{~m}$. Despite the explicit ban on throwing garbage (enshrined in both Polish and internal law of the national park), tourists leave organic waste. These are usually sandwiches, food leftovers, beverage bottles, cosmetics and droppings. This procedure leads to the enrichment of water in biogenic elements and may contribute to the development of vegetation. It should also be noted that when B. trichophyllum was first identified in Lake Mały Staw in 2003 by Zwijacz-Kozica and Żywiec [50], the species colonized mainly the north-western shore of the lake adjacent to the tourist trail. At that time, B. trichophyllum covered around $17 \%$ of the lake's surface. Our research revealed that by 2017 , the discussed species covered nearly the entire surface of Lake Mały Staw Polski. Unlike Zwijacz-Kozica and Żywiec [50], we also identified B. trichophyllum in Lake Przedni Staw Polski. The presence of species regarded as indicators of degradation of high mountain lakes [45] could testify to the long-term supply of biogenic elements, including due to heavy tourist traffic in hiking trails and sites used as points of access to the alpine lakes. According to Zwijacz-Kozica and Żywiec [50], B. trichophyllum was probably introduced to Lake Mały Staw Polski by Anas platyrhynchos L. which are fed by tourists. Such practices increase nutrient supply and contribute to eutrophication.

The effects of strong tourism pressure on aquatic ecosystems have also been discussed by other researchers. Toro et al. [72,73] investigated the influence of tourism pressure on alpine lakes in the mountainous regions of the Iberian Peninsula. Their results clearly indicate that these ecosystems were highly sensitive to the impacts of human activity. Ecosystem sensitivity was manifested by, among others, a positive correlation between the number of tourists and nutrient load in the evaluated lakes, which induced changes in the composition of aquatic biological communities, including macrophytes. The cited authors proposed several conservation and restoration measures, such as controlled livestock and visitor access to the area, and regular monitoring of the lakes' ecological status. Similar observations were made by Pickering et al. [74] in a study evaluating the influence of tourism on alpine lakes in the Australian Alps National Parks and Reserves, by Pop et al. [75] who investigated the impact of tourism on alpine lake ecosystems in Romania, and by Kangas et al. [76] who examined the influence of ski resorts on the quality of water in boreal lakes of north Finland. Pop et al. [75] also found that many tourists fail to observe hiking rules, which exerts negative effects on lakes situated in the proximity of hiking trails. At the end of the summer season, the cited authors reported considerable amounts of waste and sewage generated by tourists on the investigated mountain trails. Layers of waste were identified at the bottom of the analyzed lake (food discarded by tourists was found in the top layer). Visitors also left behind waste in the vicinity of the lake. These observations are highly consistent with our findings.

The results of the cited research indicate that the pressures resulting from growing tourist traffic pose not only a local (encountered in Poland), but also a global problem which needs to be addressed. Thus, sustainable tourism development is a very important consideration.

\section{Recommendations of the Hiking Trail Changes}

The changes proposed by the authors are presented in Figure 9. Alternative routes were mapped to move tourist traffic away from lake shores and minimize anthropogenic pressure.

The results of this study indicate that access to the examined lakes should be limited (Figures 9 and 10). Tourist infrastructure in the evaluated trail segments should be upgraded, for example by introducing barriers to separate visitors from the lakes (segments number 2, 3, 4, 5, 6, 11, 14, 16, 17, 18, 24,26 ) and by eliminating lake access points and illegal paths (segments number 1, 7, 8, 9, 10, 12, 13, 15, 25, 28, 29, 30, 31, and an illegal path south of Lake Zadni Staw Polski) (Figure 7). 


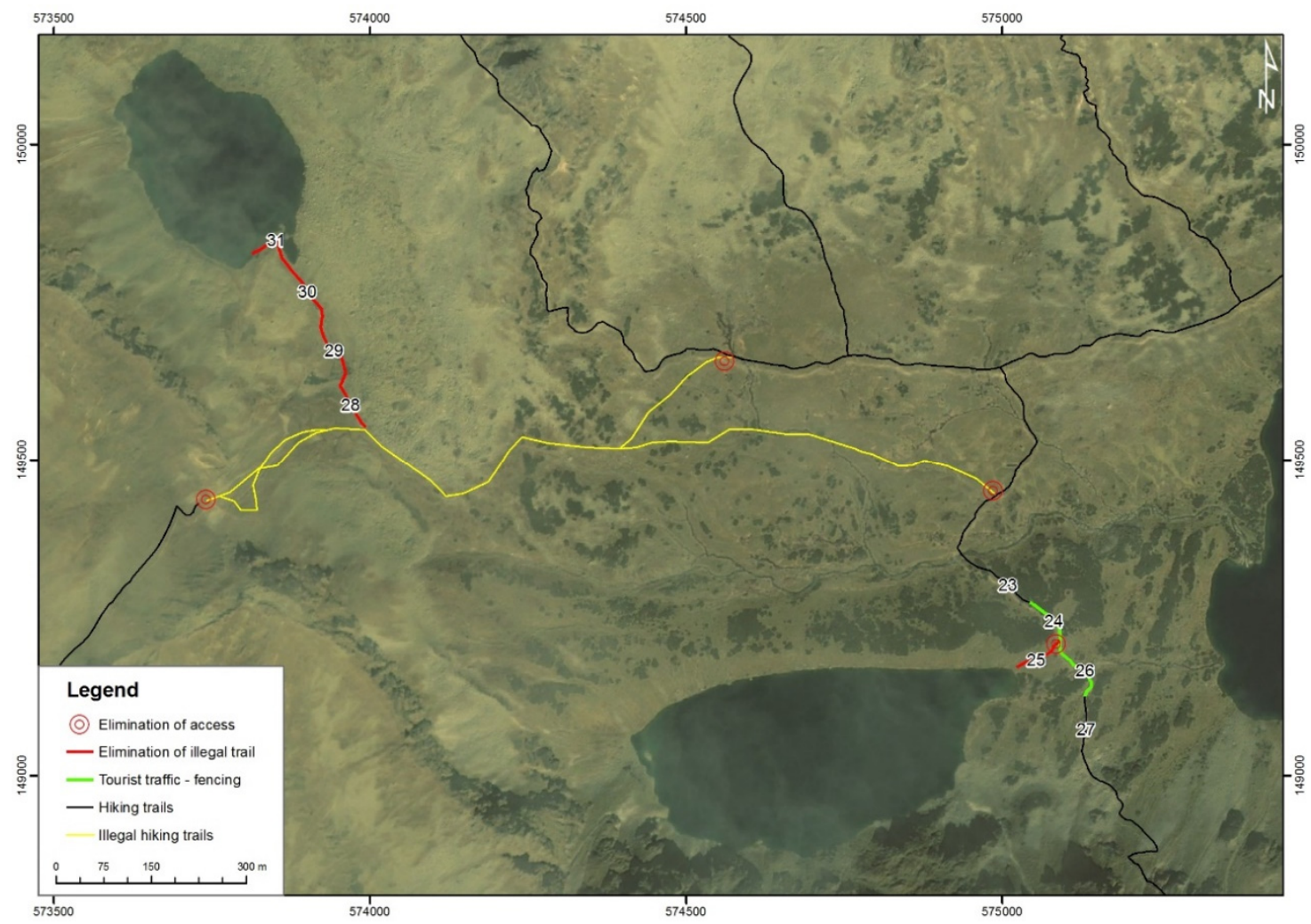

Figure 9. Proposed modifications to the hiking trail in the area of Lakes Zadni Staw Polski and Wole Oko.

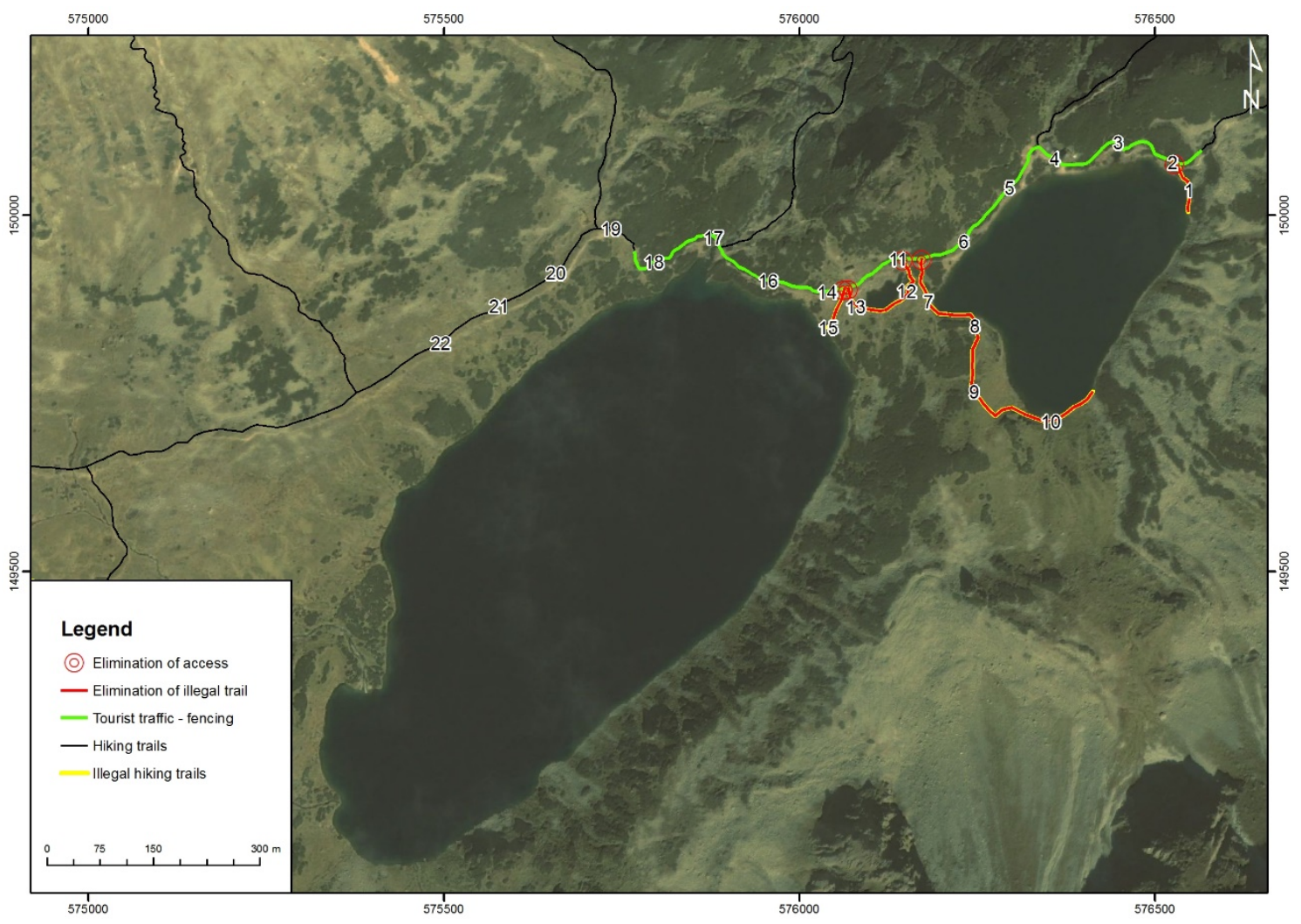

Figure 10. Proposed modifications to the hiking trail in the area of Lakes Przedni Staw Polski, Mały Staw Polski and Wielki Staw Polski. 
Tourist infrastructure should be upgraded not only by introducing the relevant modifications in the mountain shelter, but also by adapting hiking trails to growing levels of tourist traffic. A sanitary sewer line should be built along the analyzed trail, or at least along trail segments running close to the studied lakes, and wastewater should be directed to the existing wastewater treatment plant at the shelter. Despite high cost and technical difficulty, the proposed solutions could minimize adverse changes in both biotic and abiotic elements. These requirements have to be met to gradually restore nature to its pristine state in the analyzed valley.

\section{Conclusions}

This study evaluated the alpine lakes of Przedni Staw Polski, Mały Staw Polski, Wielki Staw Polski, Czarny Staw Polski, Zadni Staw Polski and Wole Oko. The last two water bodies can be classified as ultra-oligotrophic lakes which are characterized by a very low content of organic matter. In these lakes, biogenic substances are not available to plants. Additionally, the organic matter from external sources decomposes very slowly and is nearly completely taken up by plants in the area where it is introduced to the water. It contributes to the high density of plants in places that are directly powered by biogenic elements.

The results of this study confirmed that tourist traffic contributes to the growth of aquatic vegetation in high mountain lakes, which is unfavorable for these lakes, because it contributes to accelerating their eutrophication and thus degradation (in the case of oligotrophic lakes, an increase in biodiversity is not desirable because in this way they lose their specificity). The claim that tourists are the reason for enriching the water of the studied lakes with biogens (and what follows, increases vegetation) is supported by the fact that there are no other significant external sources of biogenic material in the lakes located in the studied area. In the valley of Dolina Pięciu Stawów Polskich, grazing animals is prohibited (since 1968) [59]. There is one hostel and the so-called "Hut" - a small wooden house, which is a place of refuge for park service and Volunteer Tatra Rescue Service (TOPR) employees. The hut does not have toilets or running water. The only place where domestic and household sewage is produced is a shelter. Sewage from the shelter is discharged to a small sewage treatment plant and pre-treated, and is then discharged to the town of Zakopane. The studied lakes are located higher than the sewage treatment plant and are outside the wastewater circuit. On the other hand, tourists hiking in the proximity of the evaluated lakes leave behind organic waste, for example: sandwiches, food remnants, bottles, cosmetics and feces. Therefore, the conclusion that they are responsible for supplying biogenic elements directly to lake water is appropriate.

Submerged vegetation was identified in Lakes Przedni Staw Polski and Mały Staw Polski. The concentrations of biogenic elements and other contaminants were lower in the remaining four lakes. These water bodies are situated at considerable altitude; therefore, the above factors do not pose a considerable threat to the natural environment. However, the distance between hiking trails (including illegal paths) and the shores of potentially unaffected lakes should be monitored.

The observations made in the six analyzed lakes, as well as our previous research into two alpine lakes [41], support the formulation of several conclusions regarding the management of hiking trails and the surrounding areas. Lakes Wielki Staw Polski, Czarny Staw Polski, Zadni Staw Polski and Wole Oko are situated remotely from mountain shelters and are difficult to access due to technical complexity of the hiking trail, which contributes to environmental protection. Easier access to several segments of the hiking trail (including illegal paths) on Lakes Przedni Staw Polski, Mały Staw Polski and the eastern part of Lake Czarny Staw Polski can potentially increase the risks associated with high tourism pressure.

The research method developed by Dynowski et al. [41] for evaluating the severity of tourism pressure in Lakes Morskie Oko and Czarny Staw pod Rysami was also useful for analyzing anthropogenic impacts on the lakes in the valley of Dolina Pięciu Stawów Polskich. The original methodological assumptions were not modified for the needs of this study. According to the description of the proposed method, the size of buffer zones has to be adapted to the local landform, the distance between hiking trails and lake shores, and the distribution range of submerged vegetation. Therefore, 
only the size of buffer zones was slightly modified in the present study. Due to the specificity of hydromacrophyte distribution, the proposed method is suitable for evaluating the impact of tourism (anthropogenic pressure) on oligotrophic water bodies.

The presented studies allow to conclude that the developed method can be used not only in protected areas. After the modifications, it can also be used on other lakes, outside the national parks. Sourcing data using field inventory (scuba divers) allows the extension of the set of observed anthropogenic threats. These can be not only the risks of tourism, but also with other forms of human activity (industry, agriculture, etc.). In this case, the methodology can be used not only for high mountain lakes. This requires the development of an appropriate set of indicators for a given issue.

Author Contributions: Conceptualization, A.S., P.D. and A.Ź.-S.; Data curation, P.D. and A.Ź.-S.; Investigation, P.D. and A.Ź.-S.; Methodology, A.S.; Validation, A.S.; Visualization, P.D.; Writing—original draft, A.S., P.D., I.C. and A.Ź.-S.; Writing-review and editing, A.S., P.D., I.C. and A.Ź.-S. All authors have read and agreed to the published version of the manuscript.

Funding: This research received no external funding.

Conflicts of Interest: The authors declare no conflict of interest.

\section{References}

1. Andrews, K.S.; Williams, G.D.; Samhouri, J.F.; Marshall, K.N.; Gertseva, V.; Levin, P.S. The legacy of a crowded ocean: Indicators, status, and trends of anthropogenic pressures in the California Current ecosystem. Environ. Conserv. 2014, 42, 139-151. [CrossRef]

2. Kennish, M.J. Anthropogenic Impacts. In Encyclopedia of Estuaries; Encyclopedia of Earth Sciences Series; Kennish, M.J., Ed.; Springer: Dordrecht, The Nederlands, 2016; pp. 29-35.

3. Dubois, N.; Saulnier-Talbot, E.; Mills, K.; Gell, P.; Battarbee, R.; Bennion, H.; Chawchai, S.; Dong, X.; Francus, P.; Flower, R.; et al. First human impacts and responses of aquatic systems: A review of palaeolimnological records from around the world. Anthr. Rev. 2018, 5, 28-68. [CrossRef]

4. Bowler, D.E.; Bjorkman, A.D.; Dornelas, M.; Myers-Smith, I.H.; Navarro, L.M.; Niamir, A.; Supp, S.R.; Waldock, C.; Winter, M.; Vellend, M.; et al. Mapping human pressures on biodiversity across the planet uncovers anthropogenic threat complexes. People Nat. 2020, in press. [CrossRef]

5. Azam, M.; Alam, M.M.; Hafeez, M.H. Effects of tourism on environmental pollution: Further evidence from Malaysia, Singapore and Thailand. J. Clean. Prod. 2018, 190, 330-338. [CrossRef]

6. Drius, M.; Bongiorni, L.; Depellegrin, D.; Menegon, S.; Pugnetti, A.; Stifter, S. Tackling challenges for Mediterranean sustainable coastal tourism: An ecosystem service perspective. Sci. Total Environ. 2019, 652, 1302-1317. [CrossRef] [PubMed]

7. Brtnický, M.; Pecina, V.; Hladký, J.; Radziemska, M.; Koudelková, Z.; Klimánek, M.; Richtera, L.; Adamcová, D.; Elbl, J.; Vašinová Galiová, M.; et al. Assessment of phytotoxicity, environmental and health risks of historical urban park soils. Chemosphere 2019, 220, 678-686. [CrossRef]

8. Smith, V.H.; Schindler, D.W. Eutrophication science: Where do we go from here? Trends Ecol. Evol. 2009, 24, 201-207. [CrossRef]

9. Adamowicz, W.; Naidoo, R.; Nelson, E.; Polasky, S.; Zhang, J. Nature-Based Tourism and Recreation. In Natural Capital: Theory and Practice of Mapping Ecosystem Services; Kareiva, P., Tallis, H., Ricketts, T.H., Daily, G.C., Polasky, S., Eds.; Oxford Univ. Press: Oxford, UK, 2011; pp. 188-205.

10. Monz, C.A.; Pickering, C.M.; Hadwen, W.L. Recent advances in recreation ecology and the implications of different relationships between recreation use ecological impacts. Front. Ecol. Environ. 2013, 11, 441-446. [CrossRef]

11. Sienkiewicz, E.; Gasiorowski, M. Changes in the Trophic Status of Three Mountain Lakes-Natural or Anthropogenic Process? Pol. J. Environ. Stud. 2014, 3, 875-892.

12. Hamerlík, L.; Dobríková, D.; Szarlowicz, K.; Reczynski, W.; Kubica, B.; Šporka, F.; Bitušík, P. Lake biota response to human impact and local climate during the last 200 years: A multi-proxy study of a subalpine lake (Tatra Mountains, W Carpathians). Sci. Total. Environ. 2016, 545-546, 320-328. [CrossRef]

13. Czortek, P.; Delimat, A.; Dyderski, M.K.; Zięba, A.; Jagodziński, A.M.; Jaroszewicz, B. Climate change, tourism and historical grazing influence the distribution of Carex lachenalii Schkuhr-A rare arctic-alpine species in the Tatra Mts. Sci. Total. Environ. 2017, 618, 1628-1637. [CrossRef] [PubMed] 
14. Tomczyk, A.M.; Ewertowski, M.W.; White, P.C.L.; Kasprzak, L. A new framework for prioritising decisions on recreational trail management. Landsc. Urban Plan. 2017, 167, 1-13. [CrossRef]

15. Balmford, A.; Green, J.M.H.; Anderson, M.; Beresford, J.; Huang, C.; Naidoo, R.; Walpole, M.; Manica, A. Walk on the Wild Side: Estimating the Global Magnitude of Visits to Protected Areas. PLoS Biol. 2015, 13, e1002074. [CrossRef] [PubMed]

16. Peeters, P.; Gössling, S.; Klijs, J.; Milano, C.; Novelli, M.; Dijkmans, C.; Eijgelaar, E.; Hartman, S.; Heslinga, J.; Isaac, R.; et al. Research for TRAN Committee: Overtourism: Impact and Possible Policy Responses; European Parliament, Policy Department for Structural and Cohesion Policies: Brussels, Belgium, 2018.

17. Szromek, A.R.; Hysa, B.; Karasek, A. The Perception of Overtourism from the Perspective of Different Generations. Sustainability 2019, 11, 7151. [CrossRef]

18. Sunlu, U. Environmental Impacts of Tourism. In Local Resources and Global Trades: Environments and Agriculture in the Mediterranean Region; Options Méditerranéennes: Série A. Séminaires Méditerranéens; Camarda, D., Grassini, L., Eds.; Ciheam: Bari, Italy, 2003; pp. 263-270.

19. Dokulil, M.T. Environmental Impacts of Tourism on Lakes. In Eutrophication: Cases, Consequences and Control; Ansari, A.A., Gill, S.S., Eds.; Springer: Dordrecht, The Nederland, 2014; Volume 2, pp. 81-88.

20. Poikane, S.; Ritterbusch, D.; Argillier, C.; Białokoz, W.; Blabolil, P.; Breine, J.; Jaarsma, N.G.; Krause, T.; Kubečka, J.; Lauridsenj, T.L.; et al. Response of fish communities to multiple pressures: Development of a total anthropogenic pressure intensity index. Sci. Total Environ. 2017, 586, 502-511. [CrossRef] [PubMed]

21. Khan, M.N.; Mohannad, F. Eutrophication: Challenges and Solutions. In Eutrophication: Cases, Consequences and Control; Ansari, A.A., Gill, S.S., Eds.; Springer: Dordrecht, The Nederland, 2014; Volume 2, pp. 1-15.

22. Directive 2000/60/EC of the European Parliament and of the Council of 23 October 2000 establishing a framework for Community action in the field of water policy. Available online: https:/eur-lex.europa.eu/ legal-content/EN/ALL/?uri=CELEX\%3A32000L0060 (accessed on 7 April 2020).

23. Pavlidou, A.; Simboura, N.; Rousselaki, E.; Tsapakis, M.; Pagou, K.; Drakopoulou, P.; Assimakopoulou, G.; Kontoyiannis, H.; Panayotidis, P. Methods of eutrophication assessment in the context of the water framework directive: Examples from the Eastern Mediterranean coastal areas. Cont. Shelf. Res. 2015, 108, 156-168. [CrossRef]

24. Poikane, S.; Birk, S.; Böhmer, J.; Carvalho, L.; de Hoyos, C.; Gassner, H.; Hellsten, S.; Kelly, M.; Lyche Solheim, A.; Olin, M.; et al. A hitchhiker's guide to European lake ecological assessment and intercalibration. Ecol. Indic. 2015, 52, 533-544. [CrossRef]

25. Wu, D.; Yan, H.; Shang, M.; Shan, K.; Wang, G. Water eutrophication evaluation based on semi-supervised classification: A case study in Three Gorges Reservoir. Ecol. Indic. 2017, 81, 362-372. [CrossRef]

26. Pang, M.; Song, W.; Zhang, P.; Shao, Y.; Li, L.; Pang, Y.; Wang, J.; Xu, Q. Research into the eutrophication of an artificial playground lake near the Yangtze River. Sustainability 2018, 10, 867. [CrossRef]

27. Smol, J.P. Pollution of Lakes and Rivers: A Paleoenvironmental Perspective, 2nd ed.; Blackwell Publishing Ltd.: Oxford, UK, 2008; pp. 1-383.

28. Callisto, M.; Molozzi, J.; Barbosa, J.L.E. Eutrophication of Lakes. In Eutrophication: Cases, Consequences and Control; Ansari, A.A., Gill, S.S., Eds.; Springer: Dordrecht, The Nederland, 2014; Volume 2, pp. 55-71.

29. Dorgham, M.M. Effects of Eutrophication. In Eutrophication: Cases, Consequences and Control; Ansari, A.A., Gill, S.S., Eds.; Springer: Dordrecht, The Nederland, 2014; Volume 2, pp. $29-43$.

30. Sagehashi, M.; Sakoda, A.; Suzuki, M. A mathematical model of a shallow and Eutrophic Lake (The Keszthely Basin, Lake Balaton) and simulation of restorative manipulations. Water Res. 2001, 35, 1675-1686. [CrossRef]

31. Zhao, X.; Shen, Z.Y.; Xiong, M.; Qi, J. Key uncertainty sources analysis of water quality model using the first order error method. Int. J. Environ. Sci. Technol. 2011, 8, 137-148. [CrossRef]

32. Quan, W.; Yan, L.; Yu, Z.; Jiao, L. Advance in study of lake eutrophication models. Chin. Biodivers. 2001, 9, 168-175.

33. Lu, X.; Xu, F.; Zhan, W.; Zhao, Z.Y.; Tao, S. Current situation and development trends in lake eutrophication models. Adv. Water Sci. 2003, 14, 792-798.

34. Han, F.; Chen, Y.; Liu, Z. Advance in the eutrophication models for lakes and reservoirs. Adv. Water Sci. 2003, 14, 785-791.

35. Lyche-Solheim, A.; Feld, C.K.; Birk, S.; Phillips, G.; Carvalho, L.; Morabito, G.; Mischke, U.; Willby, N.; Søndergaard, M.; Hellsten, S.; et al. Ecological status assessment of European lakes: A comparison of metrics for phytoplankton, macrophytes, benthic invertebrates and fish. Hydrobiologia 2013, 704, 57-74. [CrossRef] 
36. Kolada, A. The effect of lake morphology on aquatic vegetation development and changes under the influence of eutrophication. Ecol. Indic. 2014, 38, 282-293. [CrossRef]

37. Catalan, J.; Grazia Barbieri, M.; Bartumeus, F.; Bitusik, P.; Botev, I.; Brancelj, A.; Cogalniceanu, D.; Manca, M.; Marchetto, A.; Ognjanova-Rumenova, N.; et al. Ecological thresholds in European alpine lakes. Freshw. Biol. 2009, 54, 2494-2517. [CrossRef]

38. Pall, K.; Moser, V. Austrian Index Macrophytes (AIM-Module 1) for lakes: A Water Framework Directive compliant assessment system for lakes using aquatic macrophytes. Hydrobiologia 2009, 633, 83-104. [CrossRef]

39. Goździejewska, A.; Glińska-Lewczuk, K.; Obolewski, K.; Grzybowski, M.; Kujawa, R.; Lew, S.; Grabowska, M. Effects of lateral connectivity on zooplankton community structure in floodplain lakes. Hydrobiologia 2016, 774, 7-21. [CrossRef]

40. Chappuis, E.; Gacia, E.; Ballesteros, E. Changes in aquatic macrophyte flora over the last century in Catalan water bodies (NE Spain). Aquat. Bot. 2011, 95, 268-277. [CrossRef]

41. Dynowski, P.; Senetra, A.; Źróbek-Sokolnik, A.; Kozłowski, J. The Impact of Recreational Activities on Aquatic Vegetation in Alpine Lakes. Water 2019, 11, 173. [CrossRef]

42. Melzer, A. Aquatic Macrophytes as Tools for Lake Management. In The Ecological Bases for Lake and Reservoir Management. Developments in Hydrobiology; Harper, D.M., Brierley, B., Ferguson, A.J.D., Phillips, G., Eds.; Springer: Dordrecht, Germany, 1999; Volume 136, pp. 181-190.

43. Cantonati, M. Flora. In High-Altitude Lakes: Pearls in the Mountain Landscape; Stoch, F., Ed.; Museo Friulano di Storia Naturale: Udine, Italy, 2006; pp. 45-66.

44. Raut, R.; Sharma, S.; Bajracharya, R.M. Biotic response to acidification of lakes-A review. Kathmandu Univ. J. Sci. Eng. Technol. 2012, 1, 171-184. [CrossRef]

45. Pall, K.; Bertrin, V.; Buzzi, F.; Boutry, S.; Dutartre, A.; Germ, M.; Oggioni, A.; Schaumburg, J.; Urbanič, G. Water Framework Directive Intercalibration Technical Report. Alpine Lake Macrophyte Ecological Assessment Methods; Poikane, S., Ed.; Publications Office of the European Union, EU: Luxembourg, 2014; pp. 1-128.

46. Rey-Boissezon, A.; Auderset Joye, D. Habitat requirements of charophytes-Evidence of species discrimination through distribution analysis. Aquat. Bot. 2015, 120, 84-91. [CrossRef]

47. Kawecka, B. Glony osiadłe na Potamogeton sp. w Morskim Oku (Algal colonization of Potamogeton sp. in Lake Morskie Oko). Acta Hydrobiol. 1966, 8, 321-328. (In Polish)

48. Kawecka, B. Algae on the artificial substratum in the Wielki Staw in the Valley of the Five Polish Lakes (High Tatra Mountains). Acta Hydrobiol. 1970, 12, 423-430.

49. Galas, J. Glony i Fauna Bezkręgowców (Algae and the Invertebrate Fauna). In Morskie Oko-Przyroda $i$ Człowiek (Lake Morskie Oko_-Nature and Man); Choiński, A., Pociask-Karteczka, J., Eds.; WTPN: Zakopane, Poland, 2014; pp. 111-125. (In Polish)

50. Zwijacz-Kozica, T.; Żywiec, M. Stanowisko Batrachium trichophyllum (Ranunculaceae) w Tatrach (A locality of Batrachium trichophyllum (Ranunculaceae) in the Tatra Mountains). Fragm. Flor. Geobot. Polonica 2004, 11, 393-396. (In Polish)

51. Ellenberg, H.; Weber, H.E.; Düll, R.; Wirth, V.; Werner, W.; Paulißen, D. Zeigerwerte von Pflanzen in Mitteleuropa. Scripta Geobotanica 18, 2nd ed.; Erich Goltze KG: Göttingen, Germany, 1992; pp. 3-258.

52. Sculthorpe, C.D. The Biology of Aquatic Vascular Plants, 1st ed.; Hodder \& Stoughton Educational: London, UK, 1967; pp. 1-623.

53. Englmaier, P. Ranunculus sect. Batrachium (Ranunculaceae): Contribution to an excursion flora of Austria and the Eastern Alps. Neilreichia 2016, 8, 97-125.

54. Les, D.H. Aquatic Dicotyledons of North America: Ecology, Life History, and Systematics, 1st ed.; CRC Press: Boca Raton, FL, USA, 2017; pp. 1-1350.

55. Źróbek, R.; Źróbek-Sokolnik, A.; Dynowski, P. Application of GIS in Natural Sciences. Current Problems with Registering Submerged Plants Assemblages for the Needs of Natura 2000 Network. In The Future with GIS. Scientific Monograph; Kereković, D., Ed.; Hrvatski Informatički Zbor-GIS Forum: Zagreb, Croatia, 2011; pp. 97-103.

56. Dynowski, P.; Źróbek-Sokolnik, A.; Ciecierska, H.; Dziedzic, J.; Piotrowicz, R. The Use of GIS Tools in the Generation of Maps Illustrating the Distribution of Protected Submerged Species-The Case of Isoetes lacustris. In GIS for Geoscientists. Scientific Monograph; Kereković, D., Ed.; Hrvatski Informatički Zbor-GIS Forum: Zagreb, Croatia, 2012; pp. 123-129. 
57. Dynowski, P.; Źróbek-Sokolnik, A.; Ciecierska, H.; Dziedzic, J.; Piotrowicz, R.; Hołdyński, C. Application of GIS and GPS tools in qualification and classification of a lake's ecological status. Pol. J. Environ. Stud. 2014, 2, 639-645.

58. Gliwicz, M. Eutrofizacja jezior tatrzańskich-Użyźnienie czy zarybienie? (Euthrophication of Tatra lakes-Fertilization or fish introduction?). Wiadomości Ekologiczne 1985, 31, 351-390. (In Polish)

59. Nyka, J. Tatry Polskie. Przewodnik. (Polish Tatras. Guide), 12th ed.; Trawers: Warszawa, Poland, $2015 ;$ p. 320. (In Polish)

60. Skrzydłowski, T. Przewodnik Przyrodniczy po Tatrach Polskich (Nature Guide of the Polish Tatras); Wydawnictwa Tatrzańskiego Parku Narodowego: Zakopane, Poland, 2013; p. 424. (In Polish)

61. Król, M. The High Tatras. Monitoring of tourist traffic in the Tatra National Park. Unpublished, manuscript in preparation.

62. Tatrzański Park Narodowy. Available online: http://tpn.pl/zwiedzaj/turystyka/statystyka (accessed on 27 January 2020).

63. Nature Conservation Act of 16 April 2004. Available online: http://prawo.sejm.gov.pl/isap.nsf/DocDetails. xsp?id=WDU20040920880 (accessed on 7 April 2020).

64. Braun-Blanquet, J. Pflanzensoziologie. Grundzüge der Vegetationskunde, 3rd ed.; Springer: Wienna, Austria, 1964; p. 865.

65. Jenks, G.F. The data model concept in statistical mapping. Int. Yearb. Cartogr. 1967, 7, 186-190.

66. Furgała-Selezniow, G.; Jankun-Woźnicka, M.; Mika, M. Lake regions under human pressure in the context of socio-economic transition in Central-Eastern Europe: The case study of Olsztyn Lakeland, Poland. Land Use Policy 2020, 90, 104350. [CrossRef]

67. Kurzyca, I.; Choiński, A.; Kaniecki, A.; Siepak, J. Water ecosystems affected by human impact within the protected area of the Tatra National Park (Poland). Oceanol. Hydrobiol. Stud. 2009, 38, 77-86. [CrossRef]

68. Gasiorowski, M.; Sienkiewicz, E. The Sources of Carbon and Nitrogen in Mountain Lakes and the Role of Human Activity in Their Modification Determined by Tracking Stable Isotope Composition. Water Air Soil Poll. 2013, 224, 1498-1514. [CrossRef] [PubMed]

69. Bombówna, M.; Wojtan, K. Long-term changes in the chemical composition of water in some Tatra lakes. Acta Hydrobiol. 1999, 41, 1-16.

70. Żelazny, M.; Wolanin, A.; Pęksa, Ł. Fizyko-Chemiczne właściwości wód (Physico-Chemical Properties of Waters). In Morskie Oko-Przyroda i Człowiek (Morskie Oko-Nature and Man); Choiński, A., Pociask-Karteczka, J., Eds.; Wydawnictwa Tatrzańskiego Parku Narodowego: Zakopane, Poland, 2014; pp. 244-257.

71. Balon, J.; Jodłowski, M.; Pociask-Karteczka, J. Sposoby Zapobiegania Degradacji wód Morskiego Oka (Preventing Water Degradation in Lake Morskie Oko). In Wody na Obszarach Chronionych (Water Bodies in Nature Conservation Areas); Partyka, J., Pociask-Karteczka, J., Eds.; IGiGP UJ, OPN, KH PTG: Kraków, Poland, 2008; pp. 317-320. (In Polish)

72. Toro, M.; Granados, I. Restoration of a small high mountain lake after recent tourist impact: The importance of limnological monitoring and palaeolimnology. Water Air Soil Poll. 2002, 2, 295-310. [CrossRef]

73. Toro, M.; Granados, I.; Robles, S.; Montes, C. High mountain lakes of the Central Range (Iberian Peninsula): Regional limnology \& environmental changes. Limnetica 2006, 25, 217-252.

74. Pickering, C.M.; Harrington, J.; Worboys, G. Environmental impacts of tourism on the Australian Alps protected areas. Judgments of protected area managers. Mt. Res. Dev. 2003, 23, 247-254. [CrossRef]

75. Pop, A.J.; Mihăiescu, R.; Ozunu, A.; Mihăiescu, T.; Oprea, M.-G.; Ardelean, I.-V.; Lehaci, I. The impact of tourism in mountain lakes ecosystems. Case study: Lake Avring, Fagaras Mountain. ProEnvironment 2011, 4 , 319-323.

76. Kangas, K.; Vuori, K.-M.; Määttä-Juntunen, H.; Siikamäki, P. Impacts of ski resorts on water quality of boreal lakes: A case study in northern Finland. Boreal Environ. Res. 2012, 17, 313-325.

(C) 2020 by the authors. Licensee MDPI, Basel, Switzerland. This article is an open access article distributed under the terms and conditions of the Creative Commons Attribution (CC BY) license (http://creativecommons.org/licenses/by/4.0/). 